Check for updates

Cite this: RSC Adv., 2018, 8, 15863

\title{
A novel strategy for the manufacture of idelalisib: controlling the formation of an enantiomert
}

\author{
Nagaraju Mekala, ${ }^{\text {ab }}$ Srinivasa Rao Buddepu, ${ }^{\text {ab }}$ Sanjay K. Dehury, ${ }^{a}$ \\ Krishna Murthy V. R. Moturu, (D) *a Sunil Kumar V. Indukuri, ${ }^{a}$ \\ Umamaheswara Rao Vasireddi ${ }^{a}$ and Atchuta R. Parimi ${ }^{\mathrm{b}}$
}

Received 15th January 2018

Accepted 13th April 2018

A novel and scalable synthesis of 5-fluoro-3-phenyl-2-[(1S)-1-(9H-purin-6-ylamino)propyl]-4(3H)quinazolinone, idelalisib 1, has been developed. This strategy controls the desfluoro impurity of 13 during reduction of nitro intermediate 4 , and also arrests the formation of the enantiomer during cyclisation of diamide 17, without affecting the neighbouring chiral centre. This process is demonstrated on a larger scale in the laboratory and achieved good chemical and chiral purities coupled with good yields.

\section{Introduction}

Quinazolinones are fused heterocyclic alkaloids and have attracted many scientists working in organic and medicinal chemistry due to their substantial and extensive range of therapeutic activities. The remarkable therapeutic activities ${ }^{1}$ such as antiinflammatory, anticonvulsant, antidiabetic, anticancer, antitussive, antibacterial, analgesic, hypnotic, and sedative activities coupled with exotic structural features have impelled a lot of activity in synthetic chemistry research groups towards the development of new synthetic strategies and methodologies for the synthesis of quinazolinone alkaloids. Till now approximately 200 naturally occurring quinazolinone alkaloids have been isolated from various sources. ${ }^{2}$

Idelalisib 1, (trade name; Zydelig), 5-fluoro-3-phenyl-2-[(1S)1-(9H-purin-6-ylamino)propyl]-4(3H)-quinazolinone is a quinazolinone drug used for the treatment of chronic lymphocytic leukemia. The substance acts as a phosphoinositide 3-kinase inhibitor; More specifically, it blocks P110 $\delta$, the delta isoform of the enzyme phosphoinositide 3-kinase. The U.S. Food and Drug Administration approved idelalisib, ${ }^{3}$ in 2014, for the treatment of relapsed Follicular B-cell non-Hodgkin Lymphoma (FL), relapsed Chronic Lymphocytic Leukemia (CLL) and relapsed Small Lymphocytic Lymphoma (SLL). The European Medicines Agency (EMA) granted idelalisib ${ }^{4}$ approval for the treatment of adult patients with Chronic Lymphocytic Leukaemia (CLL) who

${ }^{a}$ Oncology Division, Process Development Laboratories, Laurus Laboratories Limited, ICICI Knowledge Park, Turkapally, Shameerpet, Hyderabad-500 078, Telangana, India. E-mail: murthy.moturu@lauruslabs.com; Fax: +91 40 23480481; Tel: +91 40 30413393

${ }^{b}$ Department of Organic Chemistry, Food, Drugs \& Water, School of Chemistry, Andhra University, Visakhapatnam-530 003, Andhra Pradesh, India

$\dagger$ Electronic supplementary information (ESI) available. See DOI: 10.1039/c8ra00407b have received at least one prior therapy and as first line treatment in the presence of $17 \mathrm{p}$ depletion.

As part of our research programme on the development of a series of anticancer drugs, herein we disclose a novel strategy for the synthesis of idelalisib, 1. Our approach has resulted not only in achieving almost total control of undesired enantiomer of 1 , but also enhanced the yields tremendously during the cyclisation step when compared to known related reports in the literature. ${ }^{5-7}$

\section{Results and discussion}

Idelalisib was first developed by Icos corporation. ${ }^{5}$ The synthesis of idelalisib reported by Icos corporation was started with 2-fluoro-6-nitro benzoic acid (Scheme 1). Nitrobenzoic acid on treatment with oxalylchloride followed by condensation with aniline in DCM affords the corresponding 2-fluoro-6-nitro- $\mathrm{N}$ phenylbenzamide 4. Coupling of this $N$-phenylbenzamide, 4 with $N$-Boc-L-2-amino butyric acid in presence of oxalylchloride yields $N$-boc-2-amino butyrate intermediate 6 which on reduction with $\mathrm{Zn} / \mathrm{AcOH}$ affords the corresponding quinazolinone intermediate. Deprotection of Boc group followed by coupling with 6-bromopurine affords idelalisib 1. In this route reaction of $N$-Boc-L-2-amino butyric acid, $\mathbf{5}$ with nitro amide intermediate $\mathbf{4}$ is a tedious reaction. In this process only $50 \%$ conversion observed with $60 \%$ purity, due to back ward reaction. Changing the solvent medium from DCM to acetonitrile or toluene also did not give any advantage in terms of conversion and purity. In the subsequent stage, nitro group is reduced but further cyclisation is not completed to form the quinazolinone (Scheme 1).

In the second synthesis reported by Geng Fengluan et al. ${ }^{6}$ of Shandong Kangmeile Pharmaceutical Technology Co Ltd. avoided acid chloride reagent for the activation of 2-fluoro-6nitro benzoic acid, 2 instead used CDI (Scheme 1). In the reductive cyclisation of $\mathbf{6}, \mathrm{Fe} / \mathrm{AcOH}$ was used in place of $\mathrm{Zn} /$ 
<smiles>O=C(O)c1c(F)cccc1[N+](=O)[O-]</smiles>

2 2-Fluoro-6-nitro benzoic acid

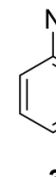

Oxalyl chloride DCM ne 4<smiles>CC(=O)c1c(F)cccc1N=O</smiles>

4<smiles>Nc1ccccc1</smiles><smiles>CC[C@H](NC(=O)OC(C)(C)C)C(=O)O</smiles>
N-Boc-L-2-amino butyric acid, 5 $50 \%$ yield $60 \%$ purity
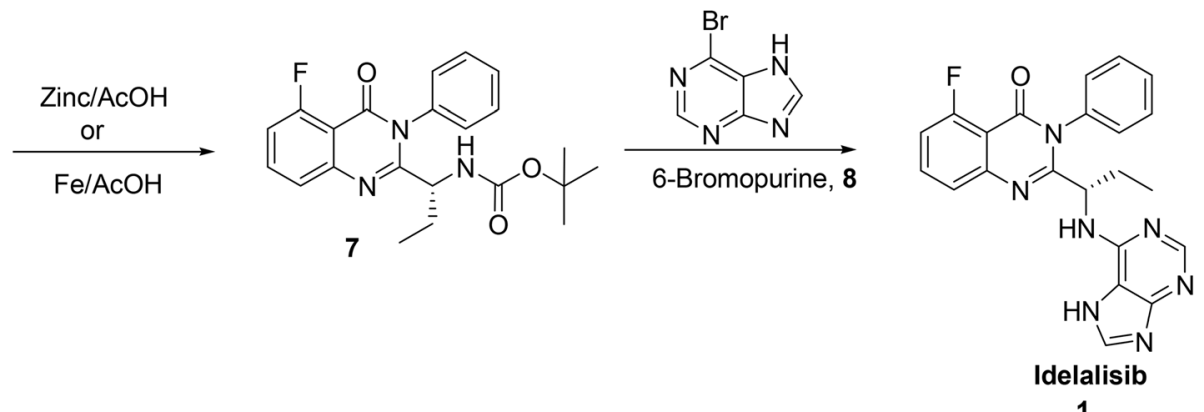

1

Scheme 1 Synthesis of idelalisib, 1 reported by Icos Corporation\& Shandong Kangmeile Pharmaceutical Technology Co Ltd.

AcOH. However, CDI is expensive to use and $\mathrm{Fe} / \mathrm{AcOH}$ reagent also not viable in commercial scale.

The third synthesis reported by Suzhou Mirac Pharma Technology Co. Ltd $^{7}$ is started with coupling of adenine 10 with 2-hydroxy butyrate 9 to afford the corresponding adenine derivative 11. Treatment of 11 with 2-amino-6-fluoro benzoic acid 2 in trimethylaluminium yields the corresponding acid intermediate 12. This acid intermediate on treatment with aniline, 3 in presence of acetic anhydride and toluene at high temperatures $\left(80-120^{\circ} \mathrm{C}\right)$ followed by cyclisation afforded idelalisib, 1. In this route coupling of aniline 3 with acid intermediate, $\mathbf{1 2}$ followed by cyclisation is a cumbersome reaction forming many products. The removal of aniline from the reaction mass to desired level as per ICH limit is also not achieved (Scheme 2).

Hence, development of idelalisib, 1 process for the manufacture requires an alternate approach to achieve ICH purity and a scalable process. As part of our process development to prepare $\mathbf{1}$ in desired cost, we have designed a novel route (Scheme 3). Unlike the innovator process (Scheme 1), N-Boc-L-2amino butyric acid, 5 was coupled with 2-amino-6-fluoro- $N$ phenylbenzamide at ambient temperature and achieved $>98 \%$ purities with reasonably good yield (Table 1 ). The reduction of nitro group for the preparation of amino intermediate is carried out at ambient temperature with conventional catalysts like $10 \% \mathrm{Pd}-\mathrm{C}$ (Table 1; entry 1), 5\% Pd-C (Table 1; entry 2), Pt-C (Table 1; entry 3 ) in a $1: 1$ mixture of methanol and dichloromethane. With these catalysts desfluoro impurity is formed up to $5 \%$ level which is very difficult to separate by means of any crystallisation from the product once it is formed. Finally, this impurity is completely controlled in the reaction itself by changing the catalyst to zinc and ammonium formate ${ }^{8}$ to afford the 2-amino-6-fluoro- $N$-phenylbenzamide in $90 \%$ yield coupled with $99 \%$ purity (Table 1 ; entry 4 ).

In the next step for the formation of amide bond, we have attempted different coupling reagents such as benzotriazol-1-yloxytripyrrolidinophosphonium hexafluorophosphate (РyBOP), $N, N^{\prime}$-dicyclohexylcarbodiimide (DCC), carbonyldiimidazole (CDI), CDI/HOBt (1-hydroxybenzotriazole) and PyBOP/HOBt for the coupling reaction of $N$-Boc-L-2-amino butyric acid with 2amino-6-fluoro- $N$-phenylbenzamide with different solvents to achieve good yield and purity (Table 2).

As shown in Table 2, the conversion of 13 was observed $\sim 50 \%$ by TLC when the reaction was carried out in DMF at room temperature using PyBOP as coupling agent. However, after work up it was found that only $10 \%$ of the product was isolated with $99 \%$ purity along with control of other isomer formation (Table 2; entry 1). Changing the solvent to acetonitrile or toluene there was not much improvement in the yield but up to $5 \%$ racemisation is observed (Table 2 ; entry 2 ) in acetonitrile whereas the isomerisation was controlled to $0.10 \%$ in the latter solvent (Table 2; entry 3). Thus we decided to use toluene as solvent in the further experiments. To our good fortune racemisation is controlled completely with similar conversion and yield when 1.0 eq. of HOBt is added to PyBOP (Table 2; entry 4). Conversion is improved in both DCC (Table 2; entry 5) and CDI (Table 2 ; entry 6 ) with improved yield $44 \%$ in the same solvent but up to $2 \%$ racemisation was observed with DCC and $0.5 \%$ with CDI. Complete conversion with reasonably good yield was observed when 1.0 eq. of HOBt is added to CDI (2.0 eq.) and also totally controlled the racemisation to $0.01 \%$ (Table 2 ; entry 7 ) at lower temperature $\left(8-12{ }^{\circ} \mathrm{C}\right)$. The same reaction at room temperature gives other isomer up to $0.15 \%$ level and at higher temperatures racemisation is observed up to $25 \%$. 
<smiles>[R]OC(=O)C(O)C(CC)C(=O)O[R]</smiles>

而

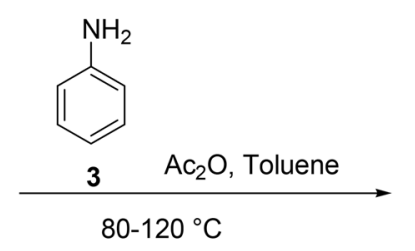<smiles>CC[C@H](Nc1ncnc2nc[nH]c12)c1nc2ccccc2c(=O)n1-c1ccccc1</smiles>

1

Scheme 2 Synthesis of idelalisib, 1 reported by Suzhou Mirac Pharma Technology Co. Ltd.

Deprotection of the Boc group in DCM/trifluoroacetic acid at $0-10{ }^{\circ} \mathrm{C}$ is achieved smoothly to afford the corresponding amine, $\mathbf{1 5}$ in quantitative yield coupled with $99 \%$ purity. This amine, $\mathbf{1 5}$ when coupled with 6-chloropurine, $\mathbf{1 6}$ in acetonitrile with diisopropylethylamine (DIPEA; 1.5 eq.) and $\mathrm{ZnCl}_{2}$ (1.5 eq.) at $80-90{ }^{\circ} \mathrm{C}$ for $10-12 \mathrm{~h}$ afforded the corresponding diamide in

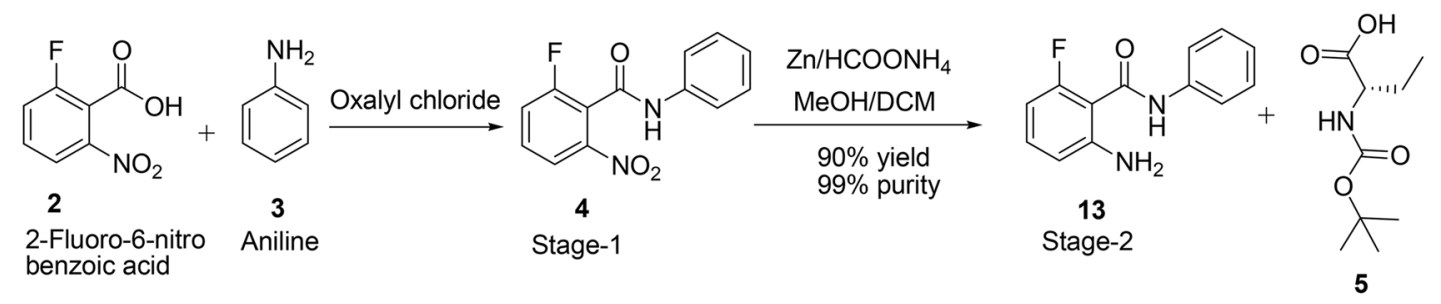

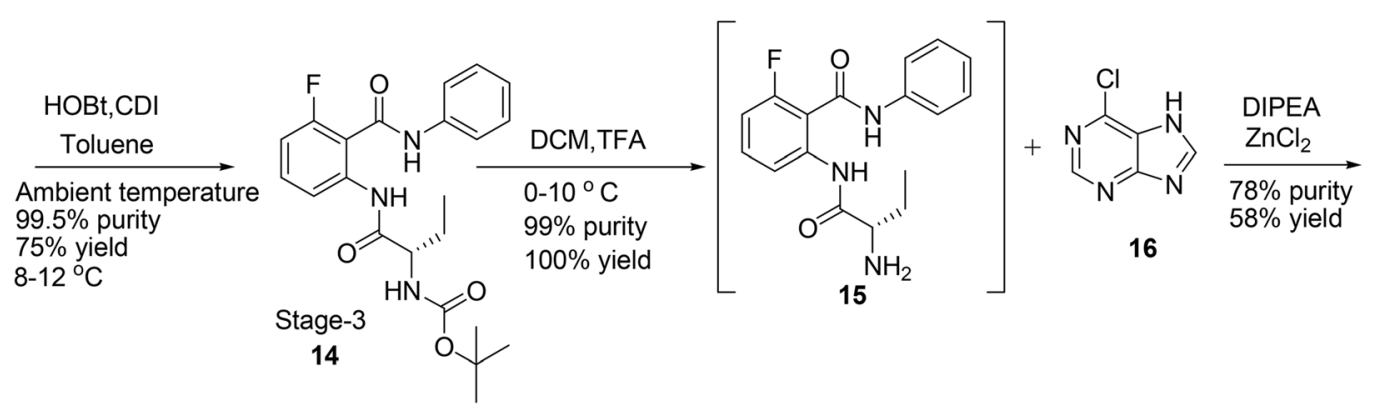<smiles>CCC(Nc1ncnc2nc[nH]c12)C(=O)Nc1cccc(F)c1C(=O)Nc1ccccc1</smiles><smiles>CCC(Nc1ncnc2nc(I)[nH]c12)c1nc2cccc(F)c2c(=O)n1-c1ccccc1</smiles>

Scheme 3 Synthesis of idelalisib, 1 by Laurus Labs Ltd. 
Table 1 Reduction of 2-fluoro-6-nitro- $N$-phenylbenzamide, 4 with different catalysts

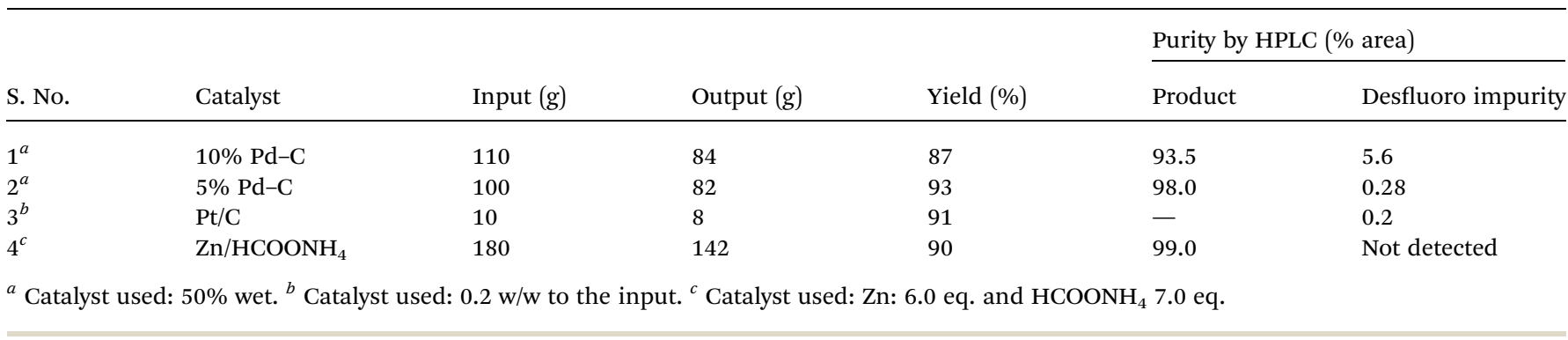

Table 2 Coupling of 2-amino-6-fluoro-N-phenylbenzamide, 13 with N-Boc-L-2-amino butyric acid ${ }^{a}$

\begin{tabular}{|c|c|c|c|c|c|c|c|c|c|}
\hline \multirow{2}{*}{ S. No. } & \multirow{2}{*}{$\begin{array}{l}\text { Coupling } \\
\text { reagent }\end{array}$} & \multirow{2}{*}{ Input $(\mathrm{g})$} & \multirow{2}{*}{ Solvent } & \multirow{2}{*}{ Output (g) } & \multirow{2}{*}{ Yield (\%) } & \multicolumn{3}{|c|}{ Purity by HPLC (\% area) } & \multirow{2}{*}{ Remarks } \\
\hline & & & & & & $\frac{\text { Chemical }}{\text { Product }}$ & \multicolumn{2}{|l|}{ Chiral } & \\
\hline 1 & РyBOp & 10 & DMF & 5 & 10 & 99.0 & 99.95 & 0.05 & $\begin{array}{l}\text { Reaction not } \\
\text { completed ( } \sim 50 \% \text { conversion observed } \\
\text { by TLC) }\end{array}$ \\
\hline 3 & РyBOp & 10 & Toluene & 5 & 28 & 99.0 & 99.9 & 0.1 & \\
\hline 4 & РyBOp/HOBt & 10 & Toluene & 5 & 28 & 99.0 & 100 & 0.0 & \\
\hline 5 & DCC & 10 & Toluene & 8 & 44 & 97.0 & 98.0 & 2.0 & $\begin{array}{l}\text { Reaction not } \\
\text { completed ( } \sim 70 \% \text { conversion observed } \\
\text { by TLC) }\end{array}$ \\
\hline 6 & CDI & 10 & Toluene & 8 & 44 & 97.0 & 99.5 & 0.5 & \\
\hline
\end{tabular}

$58 \%$ yield with $60 \%$ purity (Table 3 ; entry 1 ). Conversion is observed only $50 \%$ by TLC when the base is changed to triethylamine but only $39 \%$ yield coupled with $98 \%$ purity with $5 \%$ of enantiomer is observed after isolation (Table 3; entry 2). Reaction accelerates when zinc chloride loading is doubled (3.0 eq.) with DIPEA base and controlled the racemisation to below $0.5 \%$ (Table 3 ; entry 3 ). Reaction does not go to completion without zinc chloride and up to $20 \%$ of other isomer is formed (Table 3; entry 4). Reaction not moved at all in other bases, such as pyridine and ammonia (Table 3 ; entries $5 \& 6$ ). Conversion is also observed in water but $50 \%$ racemisation is observed.
Cyclisation of $\mathbf{1 7}$ to form the quinazoline ring closing by retaining the neighbouring chiral centre is a crucial step in the preparation of idelalisib, 1. To accomplish the cyclisation of diamide, 17 various reagents such as HMDS, HMDS/I $\mathrm{I}_{2}$ and piperdine/I $\mathrm{I}_{2}$ (Table 4) and solvents (Table 5) have been studied. Cyclization of diamide attempted in $\mathrm{Zn} / \mathrm{AcOH}$ as per innovator process $^{5 a}$ at room temperature but did not result in any conversion (Table 4; entry 1). Reaction did not progress at all with different reagent/solvent systems such as PTSA/toluene, DMF, formamide and trimethyl aluminium/toluene (Table 4; entries 2-5). Reaction also attempted with $\mathrm{ZnCl}_{2} /$ acetonitrile ${ }^{9}$

Table 3 Alkylation of 2-\{[(2S)-2-aminobutanoyl]amino\}-6-fluoro- $N$-phenylbenzamide, 15 with 6-chloropurine

\begin{tabular}{|c|c|c|c|c|c|c|c|c|}
\hline \multirow{2}{*}{ S. No. } & \multirow[b]{2}{*}{ Base/reagent } & \multirow[b]{2}{*}{ Input (g) } & \multirow[b]{2}{*}{ Output (g) } & \multirow[b]{2}{*}{ Yield (\%) } & \multirow{2}{*}{$\begin{array}{l}\text { Chemical purity } \\
\text { by HPLC (\% area) }\end{array}$} & \multicolumn{2}{|c|}{$\begin{array}{l}\text { Chiral purity } \\
\text { by HPLC (\% area) }\end{array}$} & \multirow{2}{*}{$\begin{array}{l}\text { Conversion } \\
\text { by TLC (\%) }\end{array}$} \\
\hline & & & & & & Product & Enantiomer & \\
\hline 1 & DIPEA/ZnCl 2 & 10.0 & 6.0 & 58 & 60 & 98 & 2 & 70 \\
\hline 2 & $\mathrm{TEA} / \mathrm{ZnCl}_{2}$ & 5.0 & 2.0 & 39 & 98 & 95 & 5 & 50 \\
\hline 3 & DIPEA/ZnCl 2 & 10.0 & 6.0 & 58 & 78 & 99.5 & 0.5 & 75 \\
\hline 4 & DIPEA & 10.0 & 3.0 & 29 & 60 & 80 & 20 & 30 \\
\hline 5 & Pyridine $/ \mathrm{ZnCl}_{2}$ & 3.0 & - & - & - & - & - & No conversion \\
\hline 6 & $\mathrm{NH}_{4} \mathrm{OH} / \mathrm{ZnCl}_{2}$ & 3.0 & - & - & - & - & - & \\
\hline
\end{tabular}




\begin{tabular}{|c|c|c|c|c|c|c|c|}
\hline \multirow[b]{2}{*}{ S. No. } & \multirow[b]{2}{*}{ Base/reagent } & \multirow[b]{2}{*}{ Input $(g)$} & \multirow[b]{2}{*}{ Output (g) } & \multirow[b]{2}{*}{ Yield (\%) } & \multirow{2}{*}{$\begin{array}{l}\text { Chemical } \\
\text { purity (\%) }\end{array}$} & \multicolumn{2}{|c|}{$\begin{array}{l}\text { Chiral purity } \\
\text { by HPLC (\% area) }\end{array}$} \\
\hline & & & & & & Product & Enantiomer \\
\hline 1 & $\mathrm{Zn} / \mathrm{AcOH}$ & 0.5 & - & - & - & - & - \\
\hline 2 & pTSA/toluene & 0.5 & - & - & - & - & - \\
\hline 3 & DMF & 0.5 & - & - & - & - & - \\
\hline 4 & Formamide & 0.5 & - & - & - & - & - \\
\hline 5 & Trimethyl aluminium/toluene & 2.0 & - & - & - & - & - \\
\hline 6 & $\mathrm{ZnCl}_{2} /$ acetonitrile & 5.0 & - & - & - & - & - \\
\hline 7 & $\mathrm{TPP} / \mathrm{I}_{2} /$ piperidine & 10.0 & 4.5 & 47 & 60 & 50 & 50 \\
\hline 8 & $\mathrm{HMDS} / \mathrm{I}_{2} / \mathrm{DCM}$ & 0.5 & 0.2 & 42 & 10 & 50 & 50 \\
\hline 9 & $\mathrm{HMDS} / \mathrm{I}_{2} /$ toluene & 0.5 & 0.3 & 63 & 60 & 50 & 50 \\
\hline 10 & HMDS/ $\mathrm{ZnBr}_{2} /$ toluene & 0.5 & - & - & - & - & - \\
\hline 11 & $\mathrm{HMDS} / \mathrm{I}_{2}$ & 20.0 & 11.0 & 58 & 98.9 & 50 & 50 \\
\hline 12 & $\mathrm{HMDS} / \mathrm{ZnCl}_{2} /$ acetonitrile & 20.0 & 10.0 & 53 & 99.5 & 99.95 & 0.05 \\
\hline
\end{tabular}

Table 5 Selection of solvent for cyclisation of diamide, 17 to idelalisib

\begin{tabular}{|c|c|c|c|c|c|c|c|}
\hline \multirow[b]{2}{*}{ S. No. } & \multirow[b]{2}{*}{ Solvent } & \multirow[b]{2}{*}{ Input $(\mathrm{g})$} & \multirow[b]{2}{*}{ Output (g) } & \multirow[b]{2}{*}{ Yield (\%) } & \multirow{2}{*}{$\begin{array}{l}\text { Chemical } \\
\text { purity (\%) }\end{array}$} & \multicolumn{2}{|c|}{ Chiral purity by HPLC (\%) } \\
\hline & & & & & & Product & Enantiomer \\
\hline 1 & Toluene & 40 & 20 & 48 & 78 & 50 & 50 \\
\hline 2 & $t$-Butanol & 20 & 10 & 48 & 90 & 50 & 50 \\
\hline 3 & $n$-Butanol & 3 & 2 & 64 & 80 & 50 & 50 \\
\hline 4 & 2-Methyl THF & 300 & 208 & 66 & 75 & 98.0 & 2.0 \\
\hline 5 & Acetonitrile & 30 & 20 & 64 & 99.5 & 99.95 & 0.05 \\
\hline
\end{tabular}

but found no advantage (Table 4 ; entry 6). When the reagent system is changed to $\mathrm{TPP} / \mathrm{I}_{2} /$ piperidine in acetonitrile the product was obtained in $60 \%$ purity but racemisation could not be controlled (Table 4; entry 7 ). When the reaction is carried out in $\mathrm{HMDS} / \mathrm{I}_{2}$ in DCM only $42 \%$ yield was observed with complete racemisation (Table 4; entry 8). Complete conversion is observed but racemisation is not controlled when the DCM replaced with toluene, though $60 \%$ purity of the product is obtained (Table 4; entry 9). Reaction also attempted by replacing iodine with $\mathrm{ZnBr}_{2}$ but product formation was not observed at all (Table 4 ; entry 10$).{ }^{10}$ When neat reaction was carried out in HMDS $/ \mathrm{I}_{2}{ }^{11}$ (Table 4 ; entry 11 ) $58 \%$ yield coupled with $98.9 \%$ purity was observed but racemisation could not be prevented. Finally, racemisation is completely arrested by changing the reagent to $\mathrm{HMDS} / \mathrm{ZnCl}_{2}{ }^{12}$ (Table 4; entry 12 ) in acetonitrile and obtained the compound with good purity $99.5 \%$ in $53 \%$ yield.

Having this result in hand further efforts were directed towards finding a suitable solvent to achieve ICH quality material coupled with good yield. Reaction in toluene afforded the product in $48 \%$ yield and $78 \%$ purity but racemised completely (Table 5; entry 1 ). Changing the solvent to $t$-butanol (Table 5; entry 2 ) or $n$-butanol (Table 5; entry 3 ) did not arrest the racemisation but improved yield in $n$-butanol. Reaction in 2methyl THF afforded the similar yield as observed in $n$-butanol,

Table 6 Yields and purities of scale up experiments in all stages

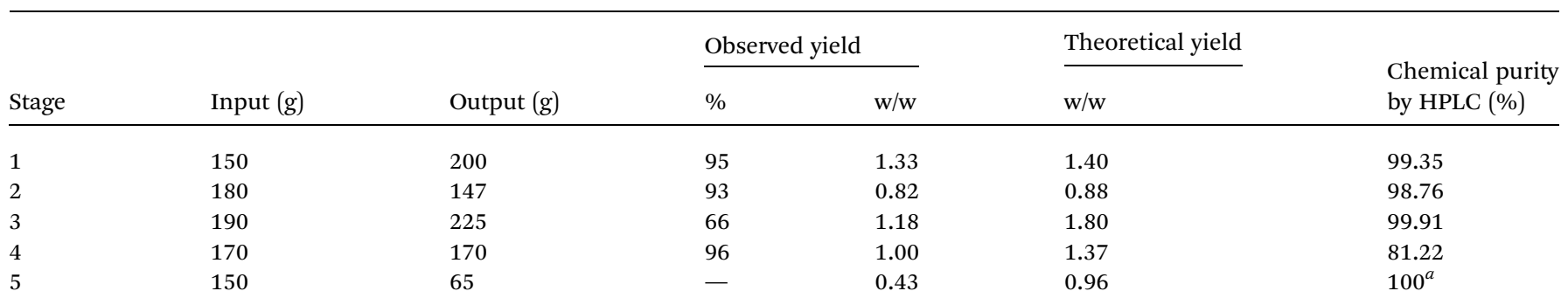

${ }^{a}$ Chiral purity also observed in $100 \%$. 
however, racemisation controlled to $2 \%$ with reasonable purity (Table 5; entry 4). No conversion was observed when the reaction was carried out in water. Finally when reaction was carried out in acetonitrile racemisation was controlled to $0.05 \%$ level along with achieving high purity of $99.95 \%$ in $64 \%$ yield (Table 5; entry 5).

Finally, with all these results in hand the optimised process was executed in 150-190 g scale in the Laboratory. We observed good yield and purities in all the steps (Table 6). ${ }^{\mathbf{1 3}}$

\section{Experimental procedures}

\section{Preparation of 2-fluoro-6-nitro- $\mathrm{N}$-phenylbenzamide, 4}

To a DCM solution of 2-fluoro-5-nitro benzoic acid (100 g; 540 $\mathrm{mmol}$ ), was added catalytic amount of DMF (7.3 g, $100 \mathrm{mmol})$ and oxalylchloride $(102.8 \mathrm{~g}, 810 \mathrm{mmol})$ at ambient temperature and maintained for $3 \mathrm{~h}$. After completion of the reaction which was monitored by TLC, the solvent was stripped off and the obtained residue was dissolved in 1,4-dioxane (80 $\mathrm{mL}$ ) and kept a side. In another RBF having $250 \mathrm{~mL} 1,4$ dioxane was added aniline $(50.3 \mathrm{~g} ; 541 \mathrm{mmol}$ ) and aq. sodium bicarbonate (90 g in 250 water) solution. To this aniline solution was added the above 1,4 -dioxane solution at $0-5{ }^{\circ} \mathrm{C}$, maintained at ambient temperature for $90 \mathrm{~min}$. After completion of the reaction which was monitored by TLC, the reaction mass was quenched into water $(1500 \mathrm{~mL})$ and stirred for $2 \mathrm{~h}$ at ambient temperature. The obtained pale yellow colour solids were filtered, washed with water to afford 2fluoro-6-nitro- $N$-phenylbenzamide in $86 \%$ yield and $99.0 \%$ purity which was proceed to next step without further purification. ${ }^{1} \mathrm{H}$ NMR data were identical with those reported in the literature. ${ }^{5 a, b}$

\section{Preparation of 2-amino-6-fluoro- $N$-phenylbenzamide, 13}

To a mixture of methanol $(500 \mathrm{~mL})$ and dichloromethane (500 mL), was added 2-fluoro-6-nitro- $N$-phenylbenzamide (100 g; $385 \mathrm{mmol}$ ), zinc powder (140 g; $2154 \mathrm{mmol}$ ) and then slowly added aq. ammonium formate solution (dissolved $170 \mathrm{~g}$ ammonium formate in $300 \mathrm{~mL}$ water) and stirred the reaction at ambient temperature for 4-5 h. The progress of the reaction was monitored by TLC. After completion of the reaction zinc salts were filtered, washed with dichloromethane $(500 \mathrm{~mL})$. The solvent from filtrate was stripped off completely under vacuum and added water $(1000 \mathrm{~mL})$ to the obtained residue. The emitted white-pale pink colour solids were filtered washed with water to afford 2-amino-6-fluoro- $\mathrm{N}$ phenylbenzamide in $90 \%$ yield. The product used as such to next step without further purification. Mp by DSC: $112.58{ }^{\circ} \mathrm{C} ;{ }^{1} \mathrm{HNMR}\left(300 \mathrm{MHz}, \mathrm{DMSO}-d_{6}\right) \delta 10.27(\mathrm{~s}, 1 \mathrm{H}), 7.63$ $(\mathrm{m}, 2 \mathrm{H}), 7.33(\mathrm{t}, J=7.5 \mathrm{~Hz}, 2 \mathrm{H}), 7.14(\mathrm{~m}, 2 \mathrm{H}), 6.75(\mathrm{~d}, J=$ $8.1 \mathrm{~Hz}, 1 \mathrm{H}), 6.42(\mathrm{~m}, 2 \mathrm{H}), 5.7(\mathrm{~s}, 2 \mathrm{H}) ;{ }^{13} \mathrm{CNMR}(75 \mathrm{MHz}$, DMSO- $\left.d_{6}\right) \delta 167.87,163.03,161.80,158.58,149.36,139.15$, 131.41, 128.50, 123.50, 120.25, 111.38, 108.60, 101.90; MS: $m /$ $z 231\left(\mathrm{M}^{+}+\mathrm{H}\right)$.

\section{Preparation of $2-\{[(2 S)-2$-amino(butoxycarbonyl)butanoyl $]$} amino\}-6-fluoro- $\mathrm{N}$-phenylbenzamide, 14

To a toluene $(500 \mathrm{~mL})$ solution of $N$-Boc-L-2-amino butyric acid (100 g; $493 \mathrm{mmol}$ ), was added 2-fluoro-6-amino- $N$ phenylbenzamide (100 g; $435 \mathrm{mmol}$ ) cooled to $8-15{ }^{\circ} \mathrm{C}$ and added carbonyldiimidazole $(140.8 \mathrm{~g}, 869 \mathrm{mmol})$ followed by 1 hydroxybenzotriazole $(117.4 \mathrm{~g}, 868.6 \mathrm{mmol})$ and stirred for 30$32 \mathrm{~h}$. After completion of the reaction which was monitored by TLC, the mass was quenched into water $(500 \mathrm{~mL})$. The obtained precipitate was filtered, washed with water. The wet material was leached with acetonitrile $(300 \mathrm{~mL})$, filtered and dried to afford off-white coloured 2-\{[(2S)-2-amino(butoxycarbonyl) butanoyl]amino\}-6-fluoro- $N$-phenylbenzamide, 14 in $67 \%$ yield. Mp by DSC: $167.48{ }^{\circ} \mathrm{C} ;{ }^{1} \mathrm{HNMR}\left(300 \mathrm{MHz}, \mathrm{DMSO}-d_{6}\right) \delta 10.54(\mathrm{~s}$, $1 \mathrm{H}), 9.93(\mathrm{~s}, 1 \mathrm{H}), 7.99(\mathrm{~d}, 1 \mathrm{H}, J=8.4 \mathrm{~Hz}), 7.74(\mathrm{~m}, 2 \mathrm{H}), 7.52(\mathrm{~m}$, $1 \mathrm{H}), 7.32(\mathrm{~m}, 2 \mathrm{H}), 7.12(\mathrm{~m}, 2 \mathrm{H}), 3.89$ (broad s, 1H), $1.74(\mathrm{~m}, 1 \mathrm{H})$, $1.55(\mathrm{~m}, 1 \mathrm{H}), 1.30(\mathrm{~s}, 9 \mathrm{H}), 0.86(\mathrm{t}, J=7.2 \mathrm{~Hz}, 3 \mathrm{H}) ;{ }^{13} \mathrm{CNMR}(75$ MHz, DMSO- $\left.d_{6}\right) \delta 171.50,161.41,160.69,157.43,155.70,138.60$, 137.70, 131.75, 128.50, 124.07, 120.93, 119.96, 117.56, 115.75, 111.12, 78.33, 56.99, 28.00, 24.38, 10.54; MS: $m / z 414\left(\mathrm{M}^{+}-\mathrm{H}\right)$.

\section{Preparation of 2-\{[(2S)-2-amino(7H-purin)butanoyl $]$ amino $\}$-6- fluoro- $N$-phenylbenzamide, 17}

To a solution of $2-\{[(2 S)$-2-amino(butoxycarbonyl)butanoyl $]$ amino\}-6-fluoro- $N$-phenylbenzamide (100 g; $241 \mathrm{mmol}$ ) in dichloromethane $(200 \mathrm{~mL})$, was added trifluoroacetic acid (200 $\mathrm{mL}$ ) and stirred for $3 \mathrm{~h}$ at ambient temperature. After completion of the reaction which was monitored by TLC, added water $(2000 \mathrm{~mL})$ to the reaction mass and adjusted the $\mathrm{pH}$ to neutral with saturated sodium bicarbonate solution. The obtained precipitate was filtered, washed with water and dried to afford 2-\{[(2S)-2-aminobutanoyl]amino $\}-6$-fluoro- $N$ phenylbenzamide, 15. Mp by DSC: $195.46{ }^{\circ} \mathrm{C} ;{ }^{1} \mathrm{HNMR}(300$ MHz, DMSO- $\left.d_{6}\right) \delta 10.64(\mathrm{~s}, 1 \mathrm{H}), 8.13$ (brs, 1H), $7.14(\mathrm{~d}, J=$ $8.4 \mathrm{~Hz}, 2 \mathrm{H}), 7.56(\mathrm{~m}, 2 \mathrm{H}), 7.50(\mathrm{~m}, 2 \mathrm{H}), 7.32(\mathrm{~m}, 1 \mathrm{H}), 7.13(\mathrm{~m}$, $1 \mathrm{H}), 3.96(\mathrm{t}, J=6 \mathrm{~Hz}, 1 \mathrm{H}), 1.74(\mathrm{q}, 2 \mathrm{H}), 0.89(\mathrm{t}, J=7.5 \mathrm{~Hz}, 3 \mathrm{H})$; ${ }^{13} \mathrm{CNMR}\left(75 \mathrm{MHz}, \mathrm{DMSO}-d_{6}\right.$ ) $\delta 168.43,160.62,158.42,158.01$, 157.28, 139.01, 135.70, 131.10, 128.70, 123.81, 120.59, 119.40, 115.29, 112.75, 53.66, 24.54, 8.82; MS: $m / z 316\left(\mathrm{M}^{+}+\mathrm{H}\right)$. The obtained compound was dissolved in acetonitrile $(500 \mathrm{~mL})$ and added 6-chloro purine (39 g; $253 \mathrm{mmol}$ ), zinc chloride (98.4 g, $722 \mathrm{mmol}$ ) followed by diisopropylamine (36.5 g, 361 mmol) and maintained at $80-100{ }^{\circ} \mathrm{C}$ for $10-12 \mathrm{~h}$. After completion of the reaction which was monitored by TLC, the reaction mass was quenched into water $(2000 \mathrm{~mL})$, stirred for $3 \mathrm{~h}$ and filtered. The obtained crude product was purified by leaching with methanol $(200 \mathrm{~mL})$ and THF $(200 \mathrm{~mL})$, filtered and dried to afford 2-\{[(2S)-2-amino(7H-purin)butanoyl $]$ amino\}-6-fluoro- $N$-phenylbenzamide, 17 in $60 \%$ yield. Mp by DSC: $267.99{ }^{\circ} \mathrm{C} ;{ }^{1} \mathrm{HNMR}\left(300 \mathrm{MHz}, \mathrm{DMSO}-d_{6}\right) \delta 12.96(\mathrm{~s}, 1 \mathrm{H})$, $10.47(\mathrm{~s}, 1 \mathrm{H}), 10.10(\mathrm{~s}, 1 \mathrm{H}), 8.14(\mathrm{t}, J=10.2 \mathrm{~Hz}, 2 \mathrm{H}), 7.89(\mathrm{~d}, J=$ $8.1 \mathrm{~Hz}, 2 \mathrm{H}), 7.82(\mathrm{~d}, J=5.4 \mathrm{~Hz}, 1 \mathrm{H}), 7.48(\mathrm{~m}, 2 \mathrm{H}), 7.24(\mathrm{~m}, 2 \mathrm{H})$, 4.79 (br s, 1H), $1.96(\mathrm{~m}, 2 \mathrm{H}), 0.94(\mathrm{t}, J=7.2 \mathrm{~Hz}, 3 \mathrm{H}) ;{ }^{13} \mathrm{CNMR}$ $\left(75 \mathrm{MHz}, \mathrm{DMSO}-d_{6}\right) \delta 171.41,161.05,160.46,157.20,154.02$, 151.96, 150.00, 139.18, 138.35, 137.34, 131.50, 131.37, 128.57, 
123.93, 119.71, 118.30, 116.50, 111.37, 111.06, 56.34, 24.39, 10.70; MS: $m / z$ 434( $\left.\mathrm{M}^{+}+\mathrm{H}\right)$.

\section{Preparation of 5-fluoro-3-phenyl-2-[(1S)-1-(9H-purin-6-} ylamino)propyl]-4(3H)-quinazolinone, 1(idelalisib)

To a solution of $2-\{[(2 S)-2$-amino( $7 H$-purin)butanoyl $]$ amino $\}-6$ fluoro- $N$-phenylbenzamide, $50 \mathrm{~g}, 115 \mathrm{mmol})$, in acetonitrile (250 $\mathrm{mL}$ ) was added zinc chloride (51 g, $374 \mathrm{mmol})$, hexamethyldisilazane (55.9 g, $347 \mathrm{mmol}$ ) and maintained the reaction mass at reflux for $4 \mathrm{~h}$. After completion of the reaction which was monitored by TLC, the reaction mass was quenched into water $(1250 \mathrm{~mL})$, stirred for 2-3 h, filtered and washed with water. The obtained crude product was dissolved in DCM $(500 \mathrm{~mL})$, adjusted $\mathrm{pH}$ to $2.0-3.0$ with $10 \%$ aq. $\mathrm{HCl}$. The DCM phase separated and fresh DCM $(500 \mathrm{~mL})$ was added to the aq. phase and neutralised with aq. sodium carbonate. The obtained product is filtered, washed with water, dried and finally recrystallized from acetonitrile $(500 \mathrm{~mL})$ to afford a white coloured 5-fluoro-3-phenyl-2-[(1S)-1-(9H-purin-6-ylamino)propyl]$4(3 H)$-quinazolinone, 1 in $60 \%$ yield and $99.9 \%$ purity. The spectral data of the compound were identical with those reported in the literature. ${ }^{5 a, b}$

\section{Conclusion}

In summary, we successfully developed a facile, novel and scalable strategy to prepare idelalisib. Cyclisation of the diamide without affecting the neighboring chiral center which is a challenging step was achieved smoothly. We further optimized this process and demonstrated the preparation in larger scale in the laboratory.

\section{Conflicts of interest}

There are no conflicts to declare.

\section{Acknowledgements}

The authors wish to thank Dr Satyanarayana Chava, CEO and Dr Srihari Raju Kalidindi, Executive Director, Laurus Laboratories Ltd for their continuous encouragement and support. We also thank Mr. Narasimha Rao DVL and other Senior Management for their helpful discussions in carrying out this work.

\section{Notes and references}

1 (a) D. J. Hart, ARKIVOC, 2010, 32; (b) J. P. Michael, Nat. Prod. Rep., 2008, 25, 166; (c) J. P. Michael, Nat. Prod. Rep., 2007, 24, 223; (d) J. P. Michael, Nat. Prod. Rep., 2005, 22, 603; (e) J. P. Michael, Nat. Prod. Rep., 2004, 21, 650; (f) J. P. Michael, Nat. Prod. Rep., 2002, 19, 7197; $(g)$ J. P. Michael, Nat. Prod. Rep., 2003, 20, 47; (h) A. L. D'yakonov and M. V. Telezhenetskaya, Chem. Nat. Compd., 1997, 33, 221; (i) I. Khan, A. Ibrar, N. Abbas and A. Saeed, Eur. J. Med. Chem., 2014, 76, 193; (j) L. He, H. Li, J. Chen and X.-F. Wu, RSC Adv., 2014, 4, 12065; (k) M. Demeunynck and I. Baussanne, Curr. Med. Chem., 2013, 20, 794; (l) S. B. Mhaske and N. P. Argade, Tetrahedron, 2006, 62, 9787; $(m)$ D. J. Connolly, D. Cusack, T. P. O'Sullivan and P. J. Guiry, Tetrahedron, 2005, 61, 10153; (n) Z. Ma, Y. Hano and T. Nomura, Heterocycles, 2005, 65, 2203; (o) A. Witt and J. Bergman, Curr. Org. Chem., 2003, 7, 659; (p) S. R. Padala, P. R. Padi and V. Thipireddy, Heterocycles, 2003, 60, 183.

2 U. A. Kshirsagar, Org. Biomol. Chem., 2015, 13, 9336.

3 https://www.accessdata.fda.gov/drugsatfda_docs/label/2014/ 206545lBl.pdf.

$4 \mathrm{http} / /$ www.ema.europa.eu/ema/index.jsp?curl=/pages/ medicines/human/medicines/00384 3/human_med_001803.jsp.

5 (a) K. W. Fowler, D. Huang, E. A. Kesicki, H. C. Ooi, A. Oliver, F. Ruan, J. Treiberg and K. Deep Puri, US Pat., 8980901, 2015; (b) K. Edward and Z. Paul, PCT application, WO2005/113554, 2005; (c) Z. Paul, K. Edward, T. Jennifer, B. Lisa, R. Matthew, O. HuaChee, W. Stephen, J. Angela and F. David, Org. Lett., 2007, 9, 1415.

6 L. Guangyong, L. Xiaojun, F. Mingwei and G. Fengluan, CN patent, 104130261, 2014.

7 X. Xu, CN patent, 104262344, 2015.

8 D. Channe Gowda, B. Mahesh and S. Gowda, Indian J. Chem., 2001, 40B, 75.

9 M. R. Yadav, S. T. Shirude, A. Parmar, R. Balaraman and R. Giridhar, Chem. Heterocycl. Compd., 2006, 42, 1038.

10 S. Fujita, P. Y. Reddy and T. Toru, US Pat., 5965746, 1999. 11 X. Lanting, Y. Jiang and M. Dawei, Org. Lett., 2012, 14, 1150. 12 U. A. Kshirsagar, B. Mhaske Santosh and P. Argade Narshinha, Tetrahedron Lett., 2007, 48, 3243.

13 S. K. Dehury, N. Mekala, B. Srinivasa Rao, I. V. Sunil Kumar and V. Umamaheswara Rao, PCT International Application, 191608A1, 2017. 